\title{
SIIVOUSKEMIAN HAASTEET PUHTAUSPALVELUISSA
}

\author{
Tuula Suontamo
}

Tuula Suontamo Oy

Tiivistelmä Puhtaus on meille kaikille monella tapaa tuttu käsite. Tiedämme, että puhtaus on terveyden tekijä, olipa kysymys sitten elintarvikkeista, ympäristöstä tai meistä ihmisistä itsestämme. Elintarvikkeiden puhtautta valvotaan, ympäristön saastumista yritetään vähentää ja pidämme huolta sekä omasta henkilökohtaisesta hygieniastamme että kotiemme siisteydestä. Edellytämme myös, että julkiset tilatja ennen kaikkea oma työpaikkamme on puhdas ja viihtyisä. Kiinteistöjen homeongelmat ovat puhuttaneet suomalaisia viime vuosina kiivaasti. Keskusteluissa on noussut esiin myös puutteellisen siivouksen, lähinnä tilojen pölyisyyden aiheuttama oireilu. Myös kosketuspintojen puhtaus puhututtaa. Tutkimuksiakin asian tiimoilta on tehty. Mikäjulkisten tilojen siivouksessa sitten oikein mättää? Eikö siivouskemia enää toimi? Tekstini keskiössä on puhtauspalvelualaja tämän päivän siivoukseen ja siivouskemiaan kohdistuvat haasteet.

\section{Puhtausala muutosten pyörteissä}

Puhtausala on kokenut viime vuosikymmeninä monenlaisia muutoksia. Elinympäristömme muuttumisen myötä puhdistettaville pinnoille kerääntyy nykyään kovin erilaista likaa kuin viime vuosituhannella. Esimerkiksi liikenteen määrä on moninkertaistunut ja sen myötä myös sisätiloihin tulevan noen määrä. Pesutiloihin tulee kosmeettisten tuotteiden käytön yleistyessä entistä runsaammin noki- ja pigmenttilikaa samoin kuin erilaisten voiteiden sisältämiä rasvoja ja öljyjä. Ravintovalikoiman laajeneminen ja lääkkeiden runsas käyttö muuttavat ihmisen eritteitä ja matkailun lisääntymisen myötä altistumme eri bakteerikannoille ja epidemioille kuin aikaisemmin. Nämä kaikki muutokset ovat vaikuttaneet sekä puhdistusaineiden tuotekehitykseen että muokanneet siivouskäytäntöjä.

\section{Lainsäädäntö ja taloudellinen tilanne ohjaavat puhtausalaa}

Puhdistusaineiden tuotekehitykseen on vaikuttanut myös koko ajan kiristyvä lainsäädäntö. Terveydelle ja ympäristölle haitallisten aineosien tilalle on pitänyt löytää turvallisempi vaihtoehto, jonka puhdistustehon on kuitenkin pysyttävä samana. Tämä ei ole aina ollut helppoa. Siivouskäytännöissä on puolestaan enenevässä määrin ollut nähtävissä yhteiskuntamme kiristyvä taloustilanne. Siivousta tuotetaan yhä vain pienemmillä resursseilla työvoimaa vähentäen, siivousaikaa lyhentäen ja siivouskertoja harventaen. Rakenteissa esiintyvien kosteusvaurioiden aiheuttajaksi aikoinaan vahvasti epäilty runsas veden käyttö siivouksessa vauhditti uuden siivouskäytännön, ns. vedettömän siivouksen toteuttamista. Kyseisessä menetelmässä siivoustekstiilit valmistellaan käyttökuntoon eli niihin imeytetään puhdistusaineen käyttöliuosta jo ennen siivottavaan kohteeseen siirtymistä. Tästä syystä vesiämpäriä ei ole enää pitkiin aikoihin näkynyt siivoojien mukana. Uuden käytännön myötä helpotettiin myös siivoojien fyysistä kuormitusta ja samalla työ nopeutui. Mutta saadaanko lika pois salamannopeasti ja ilman vettä? 


\section{Puhdistustapahtuman osatekijät tänään}

Puhdistustapahtumaa voidaan pitää monien fysikaalisten ja kemiallisten tekijöiden yhteisvaikutuksena. Tapahtumat ovat pääasiassa eri faasien rajapintojen välisten vuorovaikutusvoimien muutoksia, jotka aikaansaadaan hyödyntämällä kemiallista, mekaanista ja lämpöenergiaa. Kemiallista energiaa tapahtumaan tuo puhdistusaineen käyttöliuos ja siinä olevat aineosat mukaan lukien vesi. Vesi onkin tärkeä tekijä puhdistustapahtumassa. Se kuljettaa käyttöliuoksen aineosat rajapintoihin ja auttaa lian irrottamista. Mitä vähemmän vesimolekyylejä tapahtumassa on, sitä vaikeampi kemian on toimia. Kun siivousaikakin on minimoitu, puhdistusaineellejää kovin vähän aikaa vaikuttaa. Toisin sanoen kemian osuus kuivien tilojen, kuten koulujen ja toimistojen, ylläpitosiivouksessa jää kovin pieneksi. Pyyhinnöissä ja moppauksissa lian irrottaminen jää näin ollen suurimmaksi osaksi mekaanisen energian tehtäväksi. Lämpöenergiaa kun pystytään hyödyntämään lähinnä vain pesukoneissa.

\section{Mikrokuitu puhdistaa oikein käytettynä}

Siivousvälineiden ja ennen kaikkea mikrokuituisten siivoustekstiilien huiman kehityksen ansiosta puhdasta saadaan pienellä vesimäärällä ja jopa ilman puhdistusainetta. Mikrokuituisten pyyhkeiden ja moppien lianirrotuskyky on ylivertainen esimerkiksi entisajan kalsarinlahkeeseen verrattuna. Sen lisäksi, että mikrokuidut ovat tehokkaita lian irrottajia, ne pystyvät myös sitomaan irronneen lian itseensä, ei ainoastaan siirtelemään sitä pinnalla edestakaisin. Mikrokuitupyyhe toimii parhaiten silloin, kun siinä on irrotettavaan likaan nähden sopiva määrä vettä. Nihkeytettynä se poistaa kevyesti pintaan kiinnittynyttä likaa. Lujasti kiinnittynyt lika, esimerkiksi keittiönpöytään kuivunut ruokatahra, saadaan irrotettua vain riittävästi kostutetulla mikrokuidulla. Vettä ei kuitenkaan saa olla liikaa, sillä märkä mikrokuitu ei pysty sitomaan irrottamaansa likaa. Siivoojien on noudattava tarkasti valmistajien antamia kostutusohjeita, muuten mikrokuituiset siivouspyyhkeet ja mopit toimivat puutteellisesti. Ja on muistettava myös se, että mikrokuitu on pestävä käytön jälkeen pyykinpesukoneessa. Mahtaakohan tämä olla kaikissa kiinteistöissä mahdollista?

\section{Puhdistusainejäämät pilaavat lopputuloksen}

J oka kerta puhdistusaineiden käyttöliuoksilla kostutettuja pyyhkeitäja moppejakäytettäessä pinnoille jää jonkin verran puhdistusaineen molekyylejä oli pyyhintäväline sitten nihkeä tai kostea. Tästä on ollut seurauksena se, että pinnoille kertyy ajan kanssa puhdistusainejäämiä. Jäämiä kertyy varsinkin silloin, kun puhdistusainetta on annosteltu liikaa. Jäämät lisäävät pintojen sähkövarauksia, jotka taas puolestaan keräävät vastakkaismerkkisesti varautunutta likaa ja sitovat sen tiukasti pintaan. Vanhoina hyvinä aikoina siivoukseen kuului pintojen huuhtelu ja puhdistusainejäämiä jäi tuolloin vähemmän. Tämän hetken puhdistusaineiden aineosat ovat pääosin biohajoavia eli mikrobit hajottavat niitä ravinnokseen. Pintaan jäänyt lika yhdessä puhdistusainejäämien kanssa toimii näin ollen mikrobien kasvualustana. Tästä syystä "hallitsematon" kemia voi jopa huonontaa siivouksen lopputulosta. 


\section{Käyttöliuokset pilaantuvat nopeasti}

Siivousainevalmisteet ovat vahvoja tiivisteitä, joiden oikea annostelu vaatii miltei kemistin taitoja. Käyttöliuoksia tarvitaan päivittäin todella pieniä määriä, tämän päivän siivouksessahan tekstiilit pääasiassa vain nihkeytetään neutraalilla tai heikosti emäksisellä puhdistusaineella. Muutaman desilitran käyttöliuoksen oikeaoppinen valmistaminen on siivoojille miltei mahdotonta, heillä ei nimittäin ole pipettejä käytettävissään. Tämän vuoksi käyttöliuoksia tehdään isompia määriä kerralla, ehkä koko viikon tarve samalla kertaa. Biohajoavia aineosia sisältävien puhdistusaineiden käyttöliuokset eivät kuitenkaan pysy hygieenisinä useita päiviä. Syynä tähän on pääasiassa se, että astiat, joihin laimennokset tehdään, eivät välttämättä ole aivan puhtaita. Astiaan jääneet mikrobit lisääntyvät nopeasti ja viikon vanha käyttöliuos on useimmiten aivan käyttökelvotonta. Tätä ei puhtausalan koulutuksessa oteta vielä tarpeeksi huomioon. Alalla tarvitaan lisää kemian tietämystä.

\section{Itsepuhdistuvuus ja antibakteerisuus tämän päivän "hittejä"}

Siivousta on pyritty helpottamaan ja nopeuttamaan monin eri tavoin myös materiaalivalmistuksen keinoin. Nanoteknologian avulla pintamateriaalit ja siivousvälineet on tehty likaa hylkiviksi ja helposti puhdistuviksi, jopa itsepuhdistuviksi. Helposti puhdistuvan pinnan valmistuksessa on otettu mallia lootus-kukan, Aasian uskontojen puhtauden symbolin, rakenteesta. Superhydrofobisen lootuspinnan nanorakenteet estävät vesimolekyylin, puhumattakaan isommista molekyyleistä, tunkeutumisen pinnan sisälle, jolloin pelkkä huuhtelu puhdistaa pinnan. Itsepuhdistuvia ikkunalaseja on ollut myynnissä jo vuosien ajan. Niissä itsepuhdistuvuus perustuu titaanidioksidin fotokatalyyttiseen aktiivisuuteen. Fotokatalyysin seurauksena lika ja mikrobit hajoavat, ja sadevesi huuhtelee ne alas. Pitkinä poutakausina ikkunaan tarttuneiden linnunulosteiden irtoamista on tosin autettava pehmeällä sienellä, mutta mitään naarmuttavia hankausvälineitä ei saa käyttää.

Antibakteerisuuskin on tuttu termi siivousalalla. Myös antibakteerisissa pinnoissa ja maaleissa sekä siivousvälineissä hyödynnetään titaanidioksidin fotokatalyyttistä aktiivisuutta tai hopean ja muun biosidin, esimerkiksi triklosaanin, mikrobeja tuhoavaa vaikutusta. Antibakteerisuus ei ole kuitenkaan osoittautunut pelkästään materiaalien hyväksi ominaisuudeksi. Sen on nimittäin todettu lisäävän resistenttien bakteerikantojen muodostumista. J a ovathan biosidit toki myös ympäristöriski. Antibakteerisuus ei myöskään poista pintojen siivoustarvetta.

\section{Siivouskemia jyllää vahanpoistossa sekä korkean hygienian tiloissa}

Lattioiden vahapinnan uusiminen on sekä siivoojille että materiaaleille rankka kokemus. Entinen vaha on saatava tarkasti pois, jotta uusi vahakerros kiinnittyy pintaan tasaisesti. Tästä syystä vahanpoistossa tarvitaan vahvaa kemiaa, joko vahvoja emäksiä tai voimakkaita liuotinaineita ja runsaasti vettä. Vahanpoistoaineet ovatkin eniten siivoojaa kuormittava puhdistusaineryhmä. Kemistit ympäri maailmaa tekevät lujasti työtä valmistaakseen myös tähän työvaiheeseen turvallisia tuotteita ja siinä sitä haastetta piisaakin. 
Korkean hygienian tiloissa, kuten elintarviketiloissa, sairaaloissa ja uimahalleissa, ei selvitä ilman toimivaa kemiaa. Näissä kohteissa pinnat on saatava puhtaiksi myös näkymättömästä mikrobi-liasta. Pari vuosikymmentä sitten pinnat pestiin ensin puhdistusaineen käyttöliuoksella ja sen jälkeen puhdas pinta desinfioitiin desinfektioaineella. Ajan säästämiseksi haluttiin luopua kaksinkertaisesta työstä ja niin ryhdyttiin valmistamaan desinfioivia puhdistusaineita. Oletetaan, että lian poistaminen ja mikrobien nujertaminen onnistuvat samalla kertaa. Monet pintapuhtaustutkimukset kertovat tosin karua kieltään siitä, että systeemi ei toimi aina mallikelpoisesti. Kevyesti likaisella pinnalla se voi onnistua, mutta runsaasti likaantuneet pinnat eivät puhdistu kunnolla eivätkä mikrobitkaan ole vähentynee kuin vähän. Kemisteillä riittää töitä myös tällä sektorilla.

\section{Tulella tulta vastaan}

Bakteerityövoima otettiin käyttöön $\mathrm{mm}$. poistamaan hajuja lattiakaivoista ja viemäreistä. Nykyään bakteeri-itiöitä lisätään myös kosteiden tilojen siivousaineisiin helpottamaan vaikeasti lähestyttävien ahtaiden nurkkien ja sokkeloiden puhtaana pitämistä. Tuotteet sisältävät yleensä myös tensidejä ja muitakin tehoaineita. Bakteeri-itiöistä käyttöliuokseen aktivoituneet bakteerit lisääntyvät ja alkavat tuottaa entsyymejä. Bakteeri-itiöseoksia käytettäessä töihin saadaan eri entsyymejä, kuten lipaaseja, proteaaseja, amylaaseja ja sellulaaseja. Pinnoilla oleva lika toimii bakteerien ravintona ja lian loppuessa bakteerien lisääntyminen sekä niiden entsyymituotanto loppuu. Biologisten puhdistusaineiden vaikutus on pitkäkestoinen, sillä käyttöliuos levitetään pinnoille jajätetään huuhtelematta.

Vedettömät pisuaarit on yksi esimerkki bakteerityövoiman käytöstä pintojen puhdistumisessa. Vettä ei tarvita pisuaarin käytön jälkeen sen enempää kuin sitä puhdistettaessakaan. Roiskeita estävän muotoilun sekä erittäin sileän ja liukkaan pinnan ansiosta pisuaari pysyy helposti puhtaana, kun sisäpinnalle sumutetaan mikro-organismeja sisältävää puhdistusainetta ja jätetään vaikuttamaan. Toimintamekanismi on sama kuin biologisissa puhdistusaineissa. Ilman vettä ja puhdistusainetta toimivassa pisuaarissa yhdistyy sekä ekologisuus että taloudellisuus, ja siivoojien mukaan myös helppohoitoisuus.

\section{Siivouskoneet likaa ja vahaa irrottamaan}

Puhtausalan kehittyminen näkyy myös uusien erityyppisten siivouskoneiden yleistymisenä. Niillä tuotetaan lian irrottamisessa tarvittava mekaaninen energia ja helpotetaan näin siivoojien fyysistä kuormitusta. On yhdistelmäkoneita, jotka kastelevat lattian puhdistusaineen käyttöliuoksella, hankaavat sitä harjalla tai laikalla ja imevät lopuksi likaisen pesuveden pois. Yhdistelmäkoneita käytetään lattioiden puhdistamiseen ns. kuivissa tiloissa, kuten esimerkiksi kouluissa, päiväkodeissa ja toimistoissa. Märkätiloissa, kuten uimahalleissa, mekaanista energiaa tuotetaan yhdistelmäkoneen lisäksi lattiahoitokoneella. Lattianhoitokonetta käytetään myös vahanpoistossa tehostamaan vahanpoistoaineen vaikutusta. Uusimpana tulokkaana vahanpoistoon on kone, joka poistaa vahan ilman 
kemikaaleja, pelkästään hankaamalla. Kyseisissä laitteissa on oma imuri ja pölysäiliö, johon irrotettu vahapöly imetään. Höyrypesulaitteiden avulla puhdistustapahtumaan on saatu mukaan myös lämpöenergiaa. Uusimmat höyrypesurit tuottavat ns. kuivahöyryä, jossa on vähemmän vettä kuin perinteisellä höyrypesurilla tuotetussa höyryssä. Höyrypesussa ei tarvita puhdistusaineitta ja näin ollen pinnoille ei kerry kemikaalijäämiä.

\section{Siivousvälineiden huolto koneellistuu}

Siivoojien altistumista likaisten moppien käsittelyssä vapautuville hengittäville hiukkasille voidaan vähentää moppien esipuhdistuslaitteilla. Hiekkaisia ja roskaisia moppeja ei nimittäin voi laittaa pesukoneisiin ennen kuin niistä on irtolika harjattu tai ainakin ravisteltu pois. Kyseisessä käytännössä siivoojat joutuvat hengittämään runsaasti lattialta moppeihin tarttuneita mikrobeja ja hiukkasia, jotka altistavat heidät astmaoireille. Esipuhdistuskoneet muistuttavat sekä ulkonäöltään että toiminnaltaan kuivausrumpua. Rummun alapuolella on tyhjennettävä vetolaatikko, johon raskaat hiukkaset kerääntyvät jayläosasta lähtevän putken kautta kevyet hiukkaset ohjataan joko pölypussiin tai ilmanvaihdon poistoilmakanavaan. Koneisiin mahtuu yhdellä kerta 20 - 50 likaista moppia ja moppierän käsittelyyn kuluu aikaa kymmenisen minuuttia. Harjaaminen olisi vienyt aikaa moninkertaisesti enemmän ja rasittanut keuhkojen lisäksi siivoojan käsiä, niskaa ja hartioita. Myös siivousvälineiden, kuten harjojen, pesinten ja astioiden puhdistamiseen on valmistettu omat koneensa. Lisäksi ammattikäyttöön tarkoitetut robotti-imurit ja muut siivousrobotit tekevät tuloaan. Niiden käyttö on vielä kovin vähäistä johtuen vähäisestä tarjonnasta. Toivoa sopii, että kaikki edellä mainitut laitteet yleistyisivät mahdollisimman nopeasti heikosta taloudellisesta tilanteesta huolimatta. Näillä voidaan helpottaa siivoojien tärkeää työtä.

\section{Pintapuhtauden määrittäminen}

Yksi puhtausalalla näkyvistä muutoksista on se, että siivouksen lopputulosta voidaan arvioida muutenkin kuin silmämääräisesti. Kenttäkäyttöön soveltuvia pintapuhtauden määritystapoja on muutama ja niitä on ruvettu käyttämään keittiöympäristön lisäksi myös uimahalleissa, päiväkodeissa ja kouluissa. Yksi näistä yleistyvistä menetelmistä on luminometriaan perustuva ATP-menetelmä ja toinen on perinteinen mikrobien kasvatusmenetelmä, kuten esimerkiksi Hygicult TPC. Siivouksen tarkoitushan on ylläpitää puhtautta eli poistaa pintojen ulkonäköä, hygieenisyyttä ja kestoikää heikentävä näkyvä lika. Tämän tavoitteen saavuttaminen voidaan todeta silmämääräisellä tarkastelulla. Toinen siivouksen tavoite on ylläpitää terveyttä. Se tarkoittaa taudinaiheuttajamikrobien määrän pitämistä sellaisissa rajoissa, että ihmisen oma vastustuskyky kykenee voittamaan ne, eikä sairastumista tapahdu. Tämän tavoitteen saavuttamista voidaan todentaa bakteerikasvatusalustojen lisäksi orgaanista likaa määrittävällä tulikärpäsen entsyymin ja adenosiinitrifosfaatin välisessä reaktiossa syntyvään valoon perustuvalla ATP-menetelmällä. Näillä objektiivisilla menetelmillä voidaan varmistaa, että siivouksen tavoitteet on 
saavutettu. Mitatun puhtauden avulla päästään irti mutu-tiedosta ja voidaan kehittää niin puhdistusaineita kuin siivouskäytäntöjä.

\section{Puhtausalalla tarvitaan nuoria ja innokkaita alan kehittäjiä}

Puhtausala on yksi yhteiskuntamme toimivuuden tukipilareista eikä sen aliarvostukselle löydy yhtään järkevää perustetta. Ilman siivoojia Suomi pysähtyisi, lääke- ja elintarviketehtaat sulkisivat ovensa, sairaalat lakkautettaisiin puhumattakaan päiväkodeista ja kouluista. Alalla tarvitaan monenlaista osaamista ja monen eri alan osaajia. Kemian tuntemus auttaa puhdistusaineiden valinnassa ja käytössä, tekniikan tuntemus helpottaa puolestaan siivouskoneiden ja laitteiden käyttöä, mutta myös sosiaalisia taitoja tarvitaan, ollaanhan palveluammatissa. Opettajilla on mahdollisuus vaikuttaa nuorten ammatinvalintaan. Paras tapa lienee se, ettei hän ainakaan siirrä oppilaisiinsa mahdollisia omia ennakkoluulojaan ja asenteitaan siivousta kohtaan. Koulut voisivat näyttää esimerkkiä myös niin, että tilojen siivottavuuteen kiinnitettäisiin huomiota. Pitämällä tavarat järjestyksessä ja pinnat vapaina, siivoojilla olisi mahdollisuus puhdistaa ne säännöllisesti ja sisäilmaoireilu ja infektioiden leviäminen vähenisivät. 